УДК: 811.161.'2373

А. А. Титаренко

\title{
СТРУКТУРНО-СЕМАНТИЧНІ ОСОБЛИВОСТІ ФІРМОНІМІВ КРИВОГО РОГУ
}

Титаренко А. А. Структурно-семантичні особливості фірмонімів Кривого Рогу.

У статті розглянуто різні терміни, які вживаються для визначення назв комерційних об'єднань людей. Увагу зосереджено на аналізі структурно-семантичних ознак фірмонімів Кривого Рогу, закономірності їх виникнення і функціонування в урбанонімічному просторі. Визначаються важливі умови для створення успішного фірмоніма.

Ключові слова: урбанонімічний простір, ергонім, фірмонім, номінація, семантика.

Титаренко А. А. Структурно-семантические особенности фирмонимов Кривого Рога.

В статье рассмотрены различные термины, употребляемые для определения названий коммерческих объединений людей. Внимание сосредоточено на анализе структурно-семантических признаков фирмонимов Кривого Рога, закономерности их возникновения и функционирования в урбанонимическом пространстве. Определяются важные условия для создания успешного фирмонима.

Ключевые слова: урбанонимическое пространство, эргоним, фирмоним, номинация, семантика.

Tytarenko A. A. Structural-semantic peculiarities of firmonims of Kriviy Rih.

The article discusses the various terms used to define the name of the commercial associations of people. Attention is focused on the analysis of structural and semantic features of firmonims of Kriviy Rih, patterns of their occurrence and functioning in the urbanonimic space. The most important conditions for a successful firmonim are determined.

Key words: urbanonimic space, ergonom, firmonim, nomination, semantics.

() А. А. Титаренко, 2012.

- 72 - 
Кривий Ріг - місто обласного підпорядкування Дніпропетровської області, розташоване в центральній частині Українського кристалічного масиву у степовій зоні України. Свою назву воно отримало від форми кривого мису (рогу) на злитті річок Інгулець і Саксагань, де було засновано перше поселення.

Як і будь-яке місто, Кривий Ріг породжує велику кількість назв, що виконують роль своєрідних орієнтирів, допомагають відрізнити один об' єкт від іншого, пов'язують у нашій свідомості реальний простір міста 3 системою умовних знаків, зрозумілих і зручних його мешканцям.

Сукупність усіх назв, що входять до складу міста, які функціонують зараз і ті, що використовувалися в попередні епохи, прийнято називати урбанонімічним простором. Це назви лінійних (вулиць, провулків, проспектів, проїздів і т. ін.) і масштабних об'єктів (церков, костелів, монастирів, кінотеатрів, готелів, кафе, пам'ятників і т. ін.) [4].

Зупинимося докладніше на урбанонімічному просторі Кривого Рогу. Урбанонімічний простір Криворіжжя - це строката система власних назв, до якої входять передусім годоніми (назви вулиць), агороніми (назв площ), фірмоніми (назви комерційних об'єднань людей), гідроніми (назви водних об'єктів).

У нашій роботі ми не претендуємо охопити всі сектори урбанонімічного простору Кривого Рогу. Метою цієї статті є спроба структурно-семантичного аналізу фірмонімів. Сформульована мета передбачає постановку таких завдань: 1) розглянути різні терміни, які вживаються для визначення назв комерційних підприємств, зокрема й фірмонімів; 2) проаналізувати структурно-семантичні ознаки фірмонімів Криворіжжя; 3) дослідити закономірності виникнення та функціонування фірмонімів в урбанонімічному просторі; 4) визначити важливі умови для створення успішного фірмоніма.

У мовознавстві неодноразово робилися спроби виокремити i визначити об’ єднання людей за тими чи тими інтересами. Як правило, конкретних термінів не висувалося. Дослідники або використовували словосполучення гіперонім (поняття щодо іншого поняття, яке виражає більш загальну сутність), або давали таким явищам описові визначення: «назви закладів, партій, суспільств, колективів» [2, с. 474], «назви рухів напрямків» [2, с. 475] тощо. Згодом було введено термін ергонім, який використовують для визначення найменування ділового об'єднання людей (Н. В. Подольска), де 
останнє розуміється як будь-яка спілка, організація, заклади, корпорації, підприємства, суспільства, гуртки [5, с. 151].

На сучасному етапі в царині концепта ергонім дослідники виокремлюють різні поняття: ойкодомоніми (найменуваня, що закріплюються за певними будівлями 3 обов'язковою наявністю вивіски, НКП (назви комерційного підприємства), емпороніми (виключно торгівельні підприємства. Вичерпно обгрунтовує появу нових термінів російська дослідниця Н. В. Подольська: «Нові поняття виникають у тому чи тому творчому процесі, у тій чи тій сфері наукового пізнання. Поглиблене вивчення предмета, установлення внутрішніх зв'язків і взаємозалежності зумовлюють виникнення більш приватних понять, які згодом термінологізуються».

О. О. Белей, уводить в обіг термін фірмонім на позначення комерційно-виробничого об'єднання людей, утворений від слова фірма (організація, що веде господарську діяльність) + онім [1, с. 8]. Його вибір дослідник обгрунтовує етимологічною прозорістю, повнотою та точністю передачі позначуваного об' єкта, зауважуючи, що вживання цього терміна не порушує системність української ономастичної термінології [5, с. 8]. На наш погляд, такий термін, як видове поняття щодо родового ергоніма, $є$ зручним.

Цим терміном, услід за іншими дослідниками (Л. А. Інютіна, Д. А. Ялівець-Коновалова), позначаємо один 3 фрагментів урбанонімічного простору - найменування комерційних підприємств, зокрема торговельних закладів, банків, фірм, туристичних агентств, ріелторських контор, медичних і страхових компаній.

Фірмоніми, виступаючи соціальним знаком, існують у суспільстві і для суспільства. Більше того, у них, як у дзеркалі, відображаються зміни в соціально-економічній сфері. За радянських часів ергоніми (назви підприємств) не вирізнялися оригінальністю. Здебільшого це були складові найменування, що передбачали субстантив, який указував на форму виробництва (завод, комбінат), визначення, які називали вид продукції, що випускалася, і географічне розташування підприємства, як-от, наприклад: Криворізький гірничозбагачувальний комбінат, Південний гірничо-збагачувальний комбінат i т. ін. Фірмонім же - яскравий знак у картині світу окремої мовної особистості. У процесі створення цих онімів на передній план виходить суб' єктивний фактор: у них відбиваються смаки, уподобання номінатора, особливості сприйняття ним дійсності. Наприклад, улюблена пора року, що є і символом розквіту, надій на майбутнє, 
стала назвою ТОВ «Весна», «Літо» і т. ін.

Фірмонімія - одна 3 найбільш динамічних, відкритих систем урбанонімічного простору Кривого Рогу, яка зазнає постійних якісних та кількісних змін у зв'язку з впливом екстралінгвальних чинників, зокрема, соціальних прагнень соціуму, уподобань номінаторів тощо.

Фірмоніми, як відомо, виникали 3 розвитком торгівлі. Їх первісна форма - це здебільшого антропонім, ім'я майстра. Первісний антропонімічний вид фірмонімів був дуже поширений аж до XVII ст. (наприклад, він був звичним для музичних інструментів, зброї, збруї, взуття). У Кривому Розі фіксуємо також групу відантропонімних фірмонімів, мотивованих належністю підприємства власникові, або, які асоціюються з власником. Виокремлюємо офіційні імена: фірма 3 виготовлення тютюнових виробів «Філіп Морріс»; магазин фірмового одягу від виробника «Міхаӥл Воронін»; ресторан «У Ольги»; весільний салон «Валерія»; народно-розмовні, пестливі форми: перукарня «Оленка»; магазин жіночого одягу «Ганнуся». Доволі часто трапляються назви, пов'язані 3 нехарактерними українськими іменами, або записані українськими літерами на іншомовну манеру: перукарня «Катюша»; магазин вікон «Алекс» (пор.: рос. Александр $\rightarrow$ Алекс); салон краси «Наталі». У відантропонімній групі помічаємо, що для назв перукарень, магазинів одягу використовуються переважно жіночі імена.

Зі зростанням чисельності виробників первісного джерела фірмонімії - імені майстра - виявляється, безумовно, недостатньо. До фірмонімів залучаються імена великих людей, міфічних героїв, героїв художніх творів, топоніми, зооніми. Традиції світової фірмонімії в цьому плані простежуються і в Кривому Розі. Маємо міфоніми: салони краси «Афродита» (пор.: Афродита - богиня любові), «Юнона» (пор.: Юнона - богиня браку жіночої продуктивної сили); весільний салон «Гіменей» (пор.: Гіменей - бог подружжя); кур' срська служба «Меркурій» (пор.: Меркурій - бог торгівлі, злодійства і крилатий вісник); юридична фірма «Феміда» (пор.: Феміда - богиня правосуддя); сімейна клініка «Гестія» (пор. Гестія - богиня вогню, покровителька домашнього вогнища); міфотопоніми: супермаркет побутової техніки «Ельдорадо» (пор.: ісп. EL Dorado - «позолота» міфічна країна із золота); історичні особи: салон краси «Клеопатра» (пор.: Клеопатра - остання цариця Сгипту з македонської династії Птоломеїв); ресторан «Джеронімо» (пор.: Джеронімо - військовий 
ватажок апачі, який протягом 25 років очолював боротьбу проти вторгнення США на землю свого племені); зооніми: зоомагазини « Kim Баюн», «Мурчик»; фітоніми: магазини парфумів та побутової хімії назви яких викликають асоціації 3 приємним ароматом квітів: «Магнолія», «Лаванда», «Орхідея», «Камелія»; художні та літературні персонажі: перукарня «Попелюшка» (назва привертає увагу клієнтів своїм асоціативним зв'язком із Попелюшкою, яка перетворилася на красуню); магазин дитячих товарів «Умка» (пор.: Умка - лагідний мультиплікаційний герой-ведмедик) тощо.

На пізнішому історичному етапі виникнення фірмонімів до них починають залучатися загальні назви. Швидко були вичерпані номени дорогоцінних каменів (аметист, топаз та ін.), астрономічних і метеорологічних явищ (метеор, комета, веселка, зоря, ранок та ін.), тварин (ведмідь, верблюд та ін.) тощо. У Кривому Розі фіксуємо також номени цих груп: консалтинговий центр «Оріон» (пор.: Оріон екваторіальне сузір'я); кафе «Пасат» (пор.: Пасат - постійний сухий вітер у місцевості між тропіками та екватором); міні-готель «Вест» (пор.: Вест - західний вітер); дитячі магазини: «Жираф», «Верблюд»; магазини коштовностей: «Ящма», «Діамант», «Сапфip» тощо.

На відміну від інших власних імен, які виконують в основному функцію позначення, фірмоніми перш за все призначені для виконання закличної й естетичної функції. Вони мають відповідати вимогам атрактивності, сугестивності, легко вимовлятися i запам'ятовуватися. Це пояснює деякі особливості будови фірмонімів (у плані вираження - евфонія, відносна стислість, у плані змісту орієнтація на асоціації зі словами, що не мають пейоративних значень). Та чи всі назви фірм відповідають цим вимогам? Констатуємо недоречні іншомовні найменування, які передаються графічно українською або частково українською й англійською мовами: ресторан «Сuти pub» (пор.: англ. city - міський, pub шинок); магазин одягу «Нью лук» (пор.: англ. new - новий, look погляд, або вигляд); магазин косметики «Еколайф» (пор.: англ. ecological - екологічне, life - життя); магазин мотоциклів «Байкшоп» (пор.: англ. bike - мотоцикл, shop - магазин); салон краси «Американ бъюти» (пор.: англ. american - американська, beauty - краса) тощо. Значення i призначення таких назв пересічними громадянами не тільки не сприймається, не розуміється, а й становить проблеми у вимові. Ці немилозвучні кальки можна було б вважати товарними 
знаками, але ж не фірмонімами. У таких жахливих номінаціях у більшості фігурують запозичені слова. Зазначимо, що межі вживання іншомовних слів у лексиконі українців $є$ дуже важливим питанням культури мови. Питання про запозичені слова має розв'язуватися 3 погляду потреби. Якщо в українській мові немає для позначення поняття власного номена, то можна послуговуватися запозиченим. Якщо поняття може бути виражене українським словом, то саме йому має надаватися перевага, а не його дублетові-запозиченню. Адже значно природніше для українця звучить «Ласощуі» (крамниця кондитерських виробів), «Лагідний» (магазин продуктових товарів), «Колиба» (кав'ярня), «Чарівниия» (салон краси) тощо, ніж «Окленд» (магазин вікон), «Діавест» (магазин телефонних аксесуарів) і т. ін.

Серед інших лінгвістичних проблем, пов’ язаних із фірмонімією, заслуговує на увагу питання про семантику фірмоніма. На відміну від інших видів власних назв, особливу роль у семантичній структурі фірмоніма відіграє принцип двопланової семантики. Фірмонім не тільки позначає певний заклад із пропонованим ним товаром чи послугою, але й викликає асоціації зі значеннями інших слів, і чим позитивніші ці асоціації, тим краще фірмонім виконує свою основну функцію - функцію привертання уваги покупця. Використання принципу «двопланової семантики» певною мірою зближує фірмоніми 3 поетичною мовою, для якої цей принцип сформульований Ю. М. Тиняновим таким чином: «співвідношеня слова і лексичного тону, який викликає цілий ряд асоціацій» [8, с. 239]. Фірмонім «Вогнище» позначає не тільки установу з продажу квартир, але й викликає бажання відчути себе затишно біля домашнього вогнища. Закликає своєю назвою всіх опинитися у фантастичному світі салон квітів «Казка».

Фірмоніми, утворені внаслідок метонімічного перенесення найменувань, допомагають покупцеві краще зорієнтуватися у виді послуг, оскільки в цьому разі значення фірмоніма виникло в результаті асоціації за просторовою, часовою чи логічною суміжністю. Такі номени представлені досить широко. Деякі назви мають прозору семантику, а деякі потребують розшифрування: магазини текстильних виробів і тканин: «Вишиванка» (пор.: вишиванка - розмовна назва традиційної української вишитої сорочки), «Органза» (пор.: органза - тонка жорстка прозора тканина, зроблена з шовку, поліестера або віскози шляхом скручування двох волокон); автомагазин «Колесо», автосалон «Автопланета» і т. ін. Сюди ж віднесемо кальки з іноземної мови «Автоленд» (пор.: авто + англ. land, 
тобто автокраӥна = автомагазин), «Кодак» (магазин фототоварів і послуг), «Айсберг» (магазин холодильної техніки); магазин деревообробних станків «Агрегат» (пор.: лат. aggrego - приєдную - сукупність механізмів); магазин меблів «Канапе» (пор.: канапе - предмет меблів, подібний софі і дивану, оббитий матерією); модельні агенції «Подіум» (пор.: подіум узвишшя у вигляді вузької платформи від 50 до 100 метрів завдовжки для показу моди), «Дефіле» (пор.: дефіле $\leftarrow$ від франц. défilé - «проходження, прохід», демонстрація моделей одягу манекенницями (манекенником) у процесі їх руху по подіуму); комп'ютерний магазин «Драйв» (пор.: англ. drive - керувати, управляти); перукарня «Красуня»; кав'ярня «Смак»; ательє «Силует»; магазин музичних інструментів «Соло»; туристичні агенції: «Диліжанс» (пор.: фр. carosse de diligence - «моторний екіпаж»засіб пересування, міжміський громадський транспорт.), «Навколо світу»; кампанія (художня ковка) «Ренесанс» (пор.: фр. Renaissance, італ. Rinascimento $\longleftarrow$ від ri - «знову», або «заново народжений» - епоха в історії культури Свропи, що прийшла на зміну культурі Середніх віків i попередня культурі нового часу); косметична фірма «Аромат»; будівельна фірма «Майстер»; магазини дитячих товарів «Карапуз», «Модняшки», «Дочки-синочки»; фабрика кондитерських і кулінарних виробів «Гурман»; магазин освітлювальних приладів «Світлячок»; салон мобільного зв’ язку «Алло» тощо. За назвами технологічних процесів маємо метонімічні фірмоніми: фотомайстерня «Позитив»; типографія «Арm Принт». За походженням, місцем виготовлення товару було названо: магазин італійського одягу «Палермо» (пор.: Палермо - столиця Сициліі); магазин індійських килимів «Нью-Делі» (пор.: Нью-Делі - столиця Індіï) тощо.

Досить часто магазини, торговельні центри називають за місцем розташування, зокрема вулиці: ринок «Соимісто» розташований на житловому масиві Соцмісто; продуктові магазини, розташовані на кварталах: «95 Квартал», «97 квартал», «44 квартал», «Ювілейний», «173 квартал» (зони Кривого Рогу поділені на квартали); інколи навіть за старим місцем розташування: «Трактир на Поштовій» (пор.: Поштова - перша вулиця, яка виникла у Кривому Розі, нині проспект Карла Маркса), «Катеринославський банк». Спосіб утворення фірмонімів шляхом трансонімізації можна вважати частотним у Кривому Розі, так утворилися назви магазинів «Сонячна галерея» (на житловому масиві Сонячний), «Саксагань» (пор.: Саксагань - назва річки, що протікає у Кривому Розі) - готель; «Суха Балка» 
(підприємство), кінотеатр «Ссеніно» (на вулиці Ссеніна), кінотеатр «Зарічний» (на житловому масиві Зарічний).

Виокремлюємо також назви 3 відображенням національної специфіки. Такі найменування досить колоритні, викликають інтерес споживача: кафе «Руставелі» (пор.: Руставелі - грузинський поет 12 ст.); кафе, де можна відвідати страви різних країн з картоплі, «Картопляна xama»; кафе (італійська кухня), яке пропонує споживачам піцу (пор.: піца - італійське національне блюдо, печений млинець 3 кислого тіста 3 сиром, помідорами i різними добавками на його поверхні): «Pizza Celentano» (пор.: Челентано - італійське прізвище) тощо.

Фіксуємо досить образні і колоритні назви, пов'язані 3 відображенням українського менталітету: господарчі магазини: «Добрий господар», «Господарочка»; продуктовий магазин «Ситий татусь»; шинок «Козаџька вечеря»; ресторан «Пузата хата». 3 ваганням можна прийняти сумнівну образність останньої назви як виразника національного колориту; на жаль, і1ї засновники не вбачили семантики вульгарності і десь певної фамільярності в означенні «пузата» (словники подають слово «пузо» лише як розмовний варіант).

Трапляється багато назв, позбавлених образності, уживаних у прямому значенні, наприклад: нотаріальна консультація «Hотаріус»; магазини меблів «Меблі та дизайн», «Дім та інтер'єр»; господарчий магазин «Товари для дому»; магазин тканин «Тканини»; магазин м'ясної продукції «Ковбаси»; магазин квітів «Квіти»; кулінарія «Домашні страви» та ін.; або прямолінійно, категорично й заклично: магазини одягу: «Одягайтесь у нас», «Для майбутніх мам», «Одяг для вас»; магазин взуття «Все для взуття». Однак зазначимо, що навіть пряме вказування на пропоновані послуги чи товар виглядають значно доцільніше, а головне - ефективніше в інформуванні потенційних користувачів, ніж намагання «бути оригіналами», називаючи невмотивовано свою фірму «Лотос», адже фірма займається ремонтом та обслуговуванням техніки. Лексема лотос зазнала подвійного переосмислення значення (пор.: лотос - квітка $\rightarrow$ «лотос» - назва прального порошку $\rightarrow$ «лотос» - назва фірми). Незрозуміло, що спільного 3 «членистоногим отруйним павуком» має агрофірма «Скорпіон», або що поєднує екзотичний фрукт ківі з салоном краси «Ківі».

Іноді від незнання реального тлумачення слова або його походження виникають комічні ситуації: супермаркет будівельних матеріалів «Тако» (пор.: тако - блюдо мексиканської кухні); перукарня 
«Екстрим» (імовірно, переплутали зі значенням слова «екстравагант»; магазин білизни «Колізей» (пор.: Колізей - пам'ятка давньоримської архітектури); стоматологічна клініка «Медея» (пор.: Медея - 1. У давньогрецькій міфології - чаклунка, дружина аргонавта Ясона, яка жорстоко помстилася йому за зраду; 2. Спокуслива, ревнива та мстива жінка; а відтак, ані перше, ані друге значення в нашому прикладі недоречні); салон краси «Вернісаж» (пор.: вернісаж - перший день відкриття художньої виставки). Невдалими вважаємо назви «Лаванда» для перукарні, «Тріумф» для комісійного магазину (пор.: тріумф великий, блискучий успіх, перемога). Назва «Рудий кіm» для зоомагазину видається цілком прийнятною, чого не скажеш про ломбард «Рудий кіт». I вже зовсім неприпустимо, на наш погляд, використання жаргонної, арготичної лексики в офіційній назві установи: магазин одягу за доступними цінами «Повна шара»; казино «Шалені бабки» (пор.: бабки це жаргонне слово, що позначає гроші); магазин телефонів «Мобіла» тощо. Тим більше, що маємо більш влучні, а можливо, і пристойніші зразки метафоричних і метонімічних назв подібних установ: «Аризона», «Азарт», «Золотий бонус», «Алло», «Кінг клуб» тощо.

Однак є й позитивно оцінювані фірмоніми, які не тільки не позбавлені оригінальності, а й образні, яскраві, милозвучні, як-от, наприклад, метафоричні: магазин дитячих товарів «Сонечко - все для ваших дітей»; продуктові магазини «Злагода», «Велика ложка»; магазин сантехніки «Капля»; магазини промтоварів «Сім'я», «Простір»; ресторани «Оазис», «Танго»; салон класичних меблів «Ретро»; магазин акваріумних рибок та приладдя для їх утримання «Аква-хобi»; комп'ютерний магазин «Ума палата»; салон краси «Територія краси»; метонімічні: назви продуктових магазинів «Скринька солодощів», «Апетит»; назви взуттєвих магазинів «Ваша nара», «Інтертоп»; назви меблевих магазинів: «Парк меблів», «Меблева країна», «Меблі-град»; назви магазинів транспортної техніки «Світ човнів», «Навігатор», «Велобаза»; назви магазинів квітів «Орхідея», магазинів одягу для повних людей «Пишна краса», «Богатир - одяг для великих людей», магазину рибальського приладдя «Світ рибалки», магазину прядива «Золоте руно», магазину залізних виробів, інструментів «Залізяка»; назви туристичних фірм «Навколо cвіту», «Авіатур»; назви юридичної консультації «Гарант», адвокатського бюро «Діло» і т. ін. 
Прагнучи досягти ефективної комунікації, номінатори відшукують безліч різних, доволі оригінальних, назв для своїх підприємств. Проаналізувавши цей вид онімів Криворіжжя, вважаємо за можливе визначити кілька важливих, на наш погляд, умов створення успішного фірмоніма:

1) при створенні фірмоніма необхідно використовувати увесь спектр можливостей онімотворчості, щоб найменування не було стереотипним, безликим, беззмістовним або омонімічним; варто прагнути створити індивідуальну назву; наявність омонімії $€$ недоліком у процесі номінації фірмонімів Кривого Рогу;

2) фірмоніми повинні бути природними у вимові, милозвучними;

3) при створенні найменування адресант зобов'язаний звертати увагу на правила орфографії, що існують в сучасній українській мові;

4) у найменуваннях не повинно міститися помилкових асоціацій, що суперечать виду діяльності підприємства; слід ураховувати фонові знання номінатора i потенційного клієнта (абонент повинен зуміти розшифрувати назву, провести паралель, аналогію $з$ поняттями, що містяться в його «уявному досьє»);

5) не варто захоплюватися надмірним використанням іншомовної лексики;

6) за можливості враховувати специфіку досліджуваного регіону;

7) необхідно оцінювати потенціал імені для подальшого розвитку. Наприклад, магазин «Ластовиння», медична клініка «ПМС». Важко припустити, що підприємства 3 подібними назвами коли-небудь вийдуть на регіональний рівень, не кажучи вже про національний або міжнародний. Якщо фірма планує розвиватися i розширювати свою діяльність, то необхідно подумати, як буде виглядати жартівлива або епатуюча назва на рівні регіону.

У реальному житті буває досить важко домогтися дотримання всіх названих рекомендацій. Але врахування хоч би основних 3 них допоможе номінаторам вибрати найбільш вдалий варіант для позначення свого підприємства.

Висновок полягає в тому, що фірмонім стає ефективним (тобто виконує максимум функцій, властивих цьому виду онімів), якщо номінатор дотримується низки правил: створює чітку концепцію, аналізує потенційну аудиторію, виробляє відповідно до цього необхідні стратегії й тактики, ретельно добирає мовні засоби, оскільки сприйняття 
й оцінка фірмоніма носієм мови здійснюється за певним цілісним образом мислемовної ситуації.

Результати нашого дослідження є передумовою для подальшого опису фірмонімів як одиниць урбанонімічного простору міста 3 позиції когнітивної, комунікативної лінгвістики, лінгво-культурології, а також розробки практичного посібника для створювачів фірмонімів.

\section{Література}

1. Белей О. О. Сучасна українська ергонімія (на матеріалі власних назв підприємств Закарпатської області) : автореф. дис. на здобуття наук. ступеня канд. філол. наук : спец. 10. 02. 01 «українська мова» / О. О. Белей. - Львів, 2000. - 17 с.

2. Великобритания : Лингвострановедческий словарь 9500 единиц / А. Р. У. Рум [составит. Л.В. Колесников, Г. А. Пасечник и др.]. - М. : Рус. яз., 1980. - 480 с.

3. Єфименко I. I. Транслітерація чи перекладники-довідники [Електронний ресурс] / I. I. Єфименко // Свобода слова 2006. - № 5 - С. 8 - Режим доступу до журн. : http : //www.2000.net.ua/2000/svoboda-slova/ 8799.

4. Мезенко А. М. Из истории переименования улиц городов Белоруссии / А. М. Мезенко // Исторические названия памятники культуры : Тезисы докладов Всесоюзной научной конференции. - Минск, 1989. - С. 52- 53.

5. Подольская Н. В. Словарь русской ономастической терминологии / Н. В. Подольская. - М. : Наука, 1988. - 192 с.

6. Романюк М. I Соціально зумовлені іновації в ономастиконі Закарпаття кінця $\mathrm{XX}$ - початку XX ст. : автореф. дис. на здобуття наук. ступеня канд. філол. наук : спец. 10. 02.01 «українська мова» / М. І. Романюк. - Чернівці, 2005. - 17 с.

7. Тлумачення на словник. net [Електронний ресурс] / Режим доступу : http : //www/slovnyk.net/swrd.

8. Тынянов Ю. Н. Архаисты и новаторы / Тынянов Ю. Н. - М., 1929.- 286 с.

9. Яловец-Коновалова Д. А. Названия коммерческих предприятий: ономасиологическая классификация и функционирование в современном русском языке : автореф. дис. на соискание научной степени канд. филол. наук / Д. А. Яловец-Коновалова. Челябинск, 1997. - 24 с. 